結核性リンパ節炎による総胆管狭窄の 2 例

$\begin{array}{llllllll}\text { 片山 } & \text { 和宏*1 } & \text { 井川 } & \text { 宣*2 } & \text { 東 } & \text { 正祥*2 } & \text { 吉岡 } & \text { 博昭*2 } \\ \text { 石津 } & \text { 弘視*2 } & \text { 柏木 } & \text { 徹*2 } & \text { 満谷 } & \text { 夏樹*2 } & \text { 小泉 } & \text { 岳夫*2 } \\ \text { 桑田 } & \text { 圭二*3 } & \text { 小林 } & \text { 晏*4 } & \text { 鎌田 } & \text { 武信*1 } & & \end{array}$

要 旨：第 1 例は28歳男性, 肺結核の既往あり. 主訴は, 右季肋部痛, 発熱および黄疸であっ た. 超音波执よびCT 検査にて, 膵頭部腫大による閉塞性黄疾と診断し, PTCD にて減黄後開 腹した，膿汁を含み腫大した下部胆管リンパ節により，総胆管は圧排されていた。第 2 例は20 歳女性. 主訴は, 右上腹部痛であった。超音波にて膵頭部尰大を指摘され, 開腹にて下部胆管 に膿汁を伴ったリンパ節腫大を認めた，両者ともッベルクリン反応強陽性であった，胆道リン 八幯結核は稀な疾患で，本邦での報告は自験例 2 例を含め， 7 例に過ぎず，術前診断は困難と されている. 自験例では 2 例ともに, 胆道造影では総胆管狭窄部は平滑で, CT 検査では造影剂 にて周辺はリング状に, 内部は結節状に enhanceされた。このような画像診断所見は本症の診 断に重要と考えられた.

索引用語： 結核性リンパ節炎 総胆管狭窄 画像診断 CT 検査 閉塞性黄疸

はじめに

胆管の良性狭窄は, 胆石・術後洀痕・慢性膵炎など によって起こることが多く, リンパ節腫脹が原因とな ることは極めて稀である. 最近我々は，結核性リンパ 節炎により総胆管狭窄を呈した 2 症例を経験したので 報告する。

\section{症例}

症例 1. 28歳, 男性, 会社員.

主訴：右季助部痛. 黄疸, 発熱。

既往歴：25歳時, 非開放性肺結核にて 1 年間抗結核 療法をらけた。

家族歴：特記すべきことなし．

現病歴: 昭和60年 3 月より心䔰部不快感, 胸やけが あり，同年 5 月27日頃より右季肋部痛, 発熱, 褐色尿 および黄㡺が出現し，潮次症状増悪のため当院に入院 した.

入院時現症：身長 $167 \mathrm{~cm}$, 体重 $56 \mathrm{~kg}$, 脈拍 $52 /$ 分 整, 血圧108/64, 眼球結膜黄染。眼䀫結膜賛血無 ᄂ。表在 リンパ節触知せず，心音清，呼吸音正常．肝は，右季

\footnotetext{
"'大阪大学第 1 内科

*2大阪厚生年金病院内科

*3同 外科

*4同 病理検查科
}

肋部にて 3 横指触知したが，脾・腎は触知せず，右季 助部に圧痛を認めた．神経学的に異常を認めず。

入院時検查成績：Table 1 に示すこととく，貧血なく， 白血球は 4,800 と正常であったが，赤沈方進し， CRP 6十であった。肝機能検査では, GOT, GPT の中等度 上昇と，胆道系酔素の著明な上昇を伴ら高ビリルビン 血症を認めた。腫瘍マーカーは正常であった。ツベル クリン反応は $20 \times 12 \mathrm{~mm}$ で陽性を示した。

入院後経過：抗生剤投与により CRP, 血沈の改善は 見られたが，高ビリルビン血症は持続した，腹部超音 波検査にて肝外閉塞性黄疸と猃断し，PTCDにより減 黄を計った。

腹部超音波検查: 膵頭部に直径約 $4 \mathrm{~cm}$ の low echoic massを認め, 総胆管は同部位で狭窄を示した (Fig. 1).

ERCP：総胆管中下部に平滑な狭窄像を示した (Fig. 2).

腹部 CT 検査：plain CTにて, 石灰化を伴った膵頭 部の瘇瘤を認めた。腫瘤辺縁部は enhance CTKてリ ング状に enhanceされ, 内部は結節様に enhanceされ る部位と、全く enhanceされない部位を認めた（Fig. 3).

血管造影：腹腔動脈造影門脈相で閏脈本幹飞壁外性 圧排像を認めた。 
Table 1 Laboratory data on admission (case 1).

\begin{tabular}{|c|c|c|c|}
\hline (1) Blood & & Amylase (U) & $2220 \mathrm{U}$ \\
\hline $\mathrm{RBC}$ & $445 \times 10^{4} / \mathrm{mm}^{3}$ & (3) Coagulation & \\
\hline $\mathrm{Hb}$ & $14.0 \mathrm{~g} / \mathrm{d} l$ & Bleeding time & $5^{\prime} 30^{\prime \prime}$ \\
\hline $\mathrm{Ht}$ & $43.5 \%$ & APTT & $35.2 \mathrm{sec}$ \\
\hline WBC & $4800 / \mathrm{mm}^{3}$ & P.T & $12.7 \mathrm{sec}$ \\
\hline ESR & $71 \mathrm{~mm} / \mathrm{lh}, 108 \mathrm{~mm} / 2 \mathrm{~h}$ & (4) Serology & \\
\hline (2) Biochemistry & & CRP & $(6+)$ \\
\hline T. Bil & $8.5 \mathrm{mg} / \mathrm{d} l$ & RA & $(-)$ \\
\hline D. Bil & $6.8 \mathrm{mg} / \mathrm{d} l$ & (5) Stool & \\
\hline GOT & $107 \mathrm{U} / \mathrm{L}$ & Occult Blood & (H) \\
\hline GPT & $221 \mathrm{U} / \mathrm{L}$ & (6) Tuberculin reaction & \\
\hline $\mathrm{LDH}$ & $263 \mathrm{U} / \mathrm{L}$ & $0 \times 0$ & \\
\hline ALP & $810 \mathrm{U} / \mathrm{L}$ & $20 \times 12$ & \\
\hline$\gamma$-GTP & $246 \mathrm{U} / \mathrm{L}$ & (7) Tumor marker & \\
\hline LAP & $962 \mathrm{GR}$ & AFP & $2 \mathrm{ng} / \mathrm{m} l$ \\
\hline $\mathrm{ChE}$ & $0.74 \mathrm{D}-\mathrm{PH}$ & CEA & $0.8 \mathrm{ng} / \mathrm{m} l$ \\
\hline Chol & $194 \mathrm{mg} / \mathrm{d} l$ & CA19-9 & $11 \mathrm{U} / \mathrm{m} l$ \\
\hline Amylase (S) & $295 \mathrm{IU} / \mathrm{L}$ & IAP & $730 \mu \mathrm{g} / \mathrm{m} l$ \\
\hline
\end{tabular}

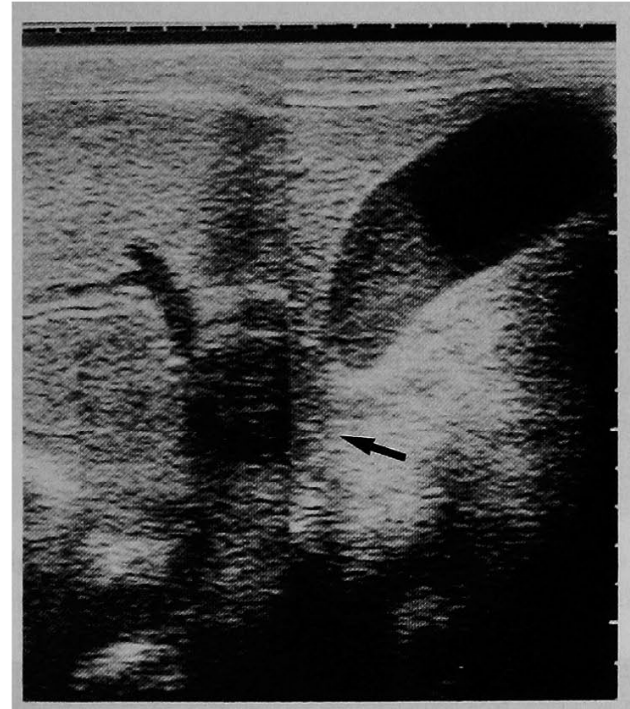

Fig. 1 Abdominal sonogram demonstrating a mass at the periportal region. (arrow)

手術所見：シェーマに示すごとく総胆管下部に，膿 汁を含み腫大したりンバ節膿瘍を認めた。総胆管・胆 䧶切除㧊よび膿演ドレナージ術施行後, 総胆管空腸吻 合術を施行した (Fig. 4).

組織像：腫大したリンパ節は，中央に広範な乾酪壊 死巣がみられ，その周辺には類上皮細胞およびラング ヘンス巨細胞を認めた。またチールネルセン染色にて 多数の抗酸菌を認め, 結核性リンパ節炎と診断した (Fig. 5).

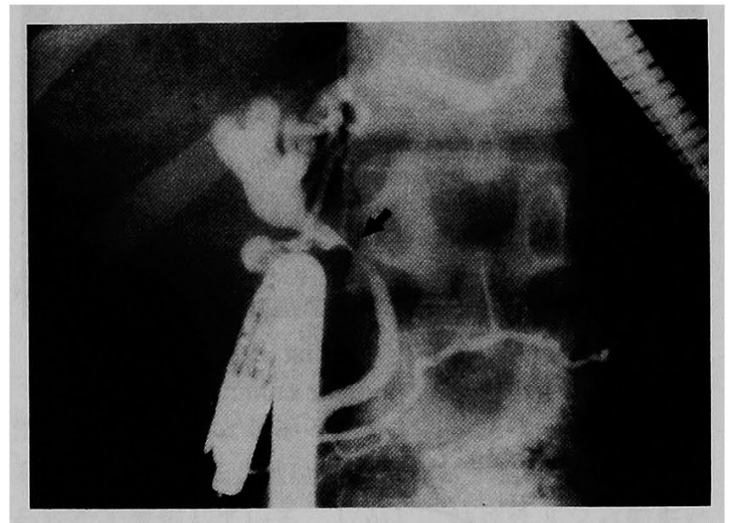

Fig. 2 ERCP showing smooth narrowing of the middle-distal common bile duct. (arrow)

症例 2, 20歳, 女性, 会社員.

主訴：右上腹部痛。

既往歴：18歳時, 虫垂炎にて手術。

家族歴：特記すべきことなし。

現病歴：昭和 61 年 3 月頃より, 右上腹部痛出現した。 精查目的にて当院内科に入院した。

入院時現症：身長 $159 \mathrm{~cm}$, 体重 $52.3 \mathrm{~kg}$, 脈拍 $88 /$ 分 整, 血压 $120 / 60$, 眼球結膜黄染なし, 眼䀫結膜貫血な し. 表在リンバ節触知せず, 心音清, 呼吸音正常, 肝・ 脾・腎は触知せず。右季胁部に压痛を認めた。神経学 的に異常を認めず。

入院時検查所見：ALP の軽度上昇とッベルクリン 反応 $48 \times 47 \mathrm{~mm}$ と強陽性を示したほか著变を認めな 


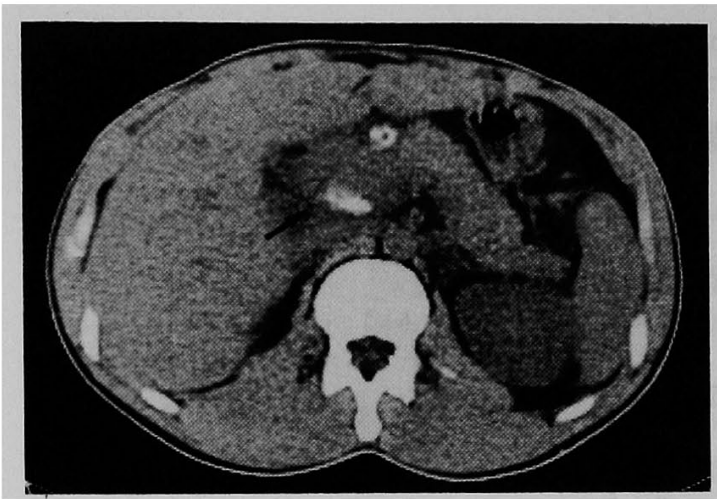

Fig. 3A Plain CT showing a calcified mass at the head of pancreas. (arrow)

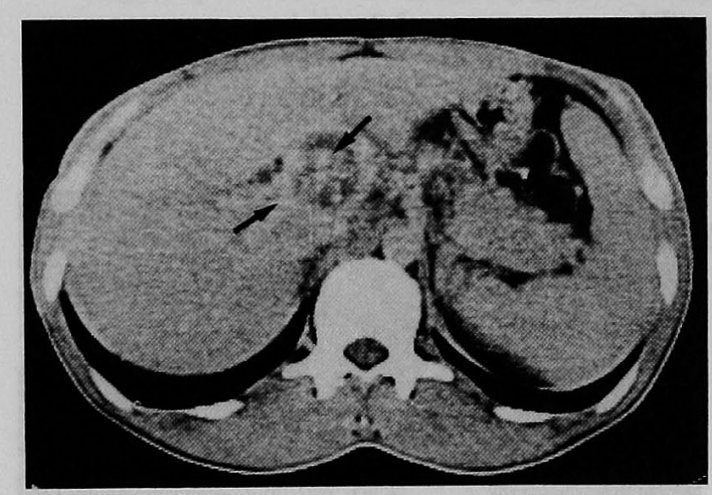

Fig. 3B Enhance CT showing ring enhancement around a mass and nodular enhancement within it. (arrow)

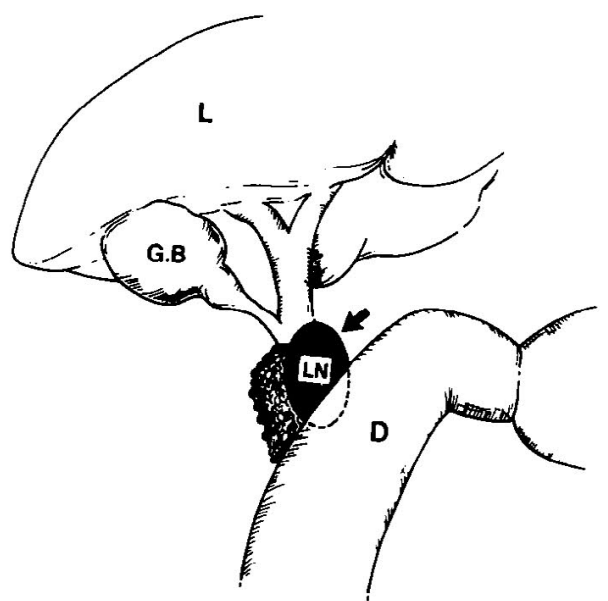

Fig. 4 The schema of operation findings. A lymph node swelling due to tuberculous adenitis was noted. (arrow) L; Liver, G.B ; Gall Bladder, D ; Duodenum, LN ; Lymph Node

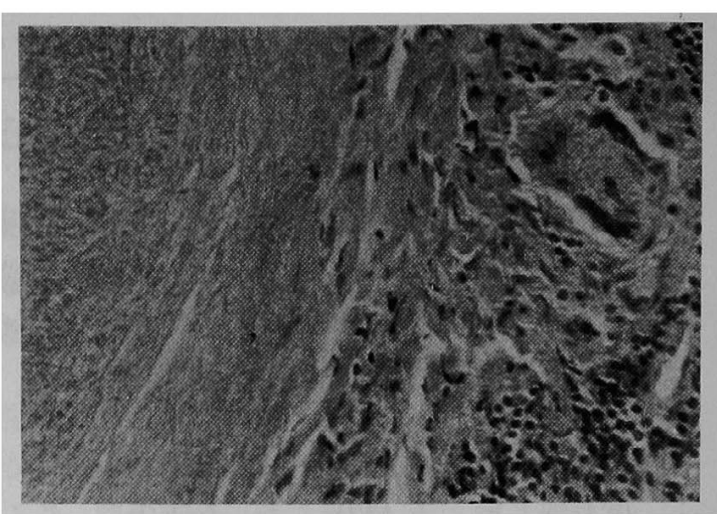

Fig. 5 Tuberculous lymphadenitis. Photomicrograph showing granuloma with caseation and multinucleated giant cell. Hematoxylin and eosin stain. $\times 400$

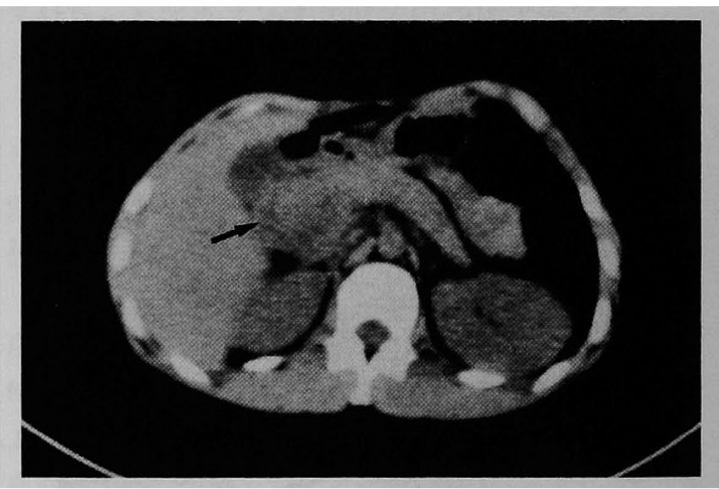

Fig. 6A Plain CT showing a mass at the head of pancreas. (arrow)

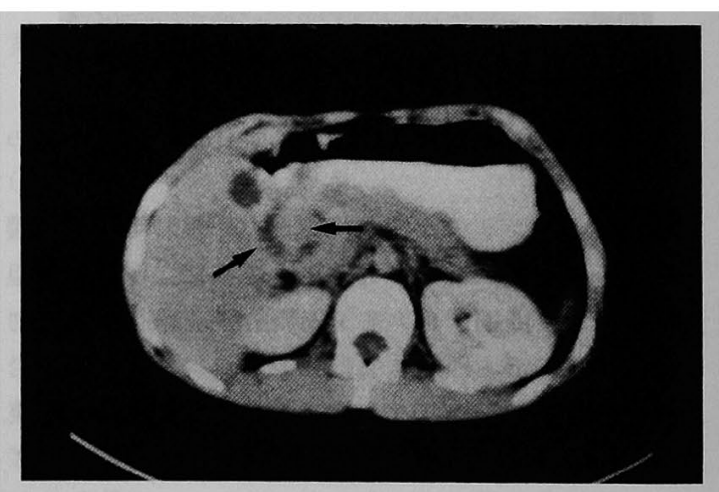

Fig. 6B Enhance CT showing ring enhancement around a mass and focal nodular enhancement within it. (arrow) 
Table 2 Laboratory data on admission (case 2).

\begin{tabular}{|c|c|c|c|}
\hline \multicolumn{2}{|l|}{ (1) Blood } & Amylase (U) & $1587 \mathrm{U}$ \\
\hline $\mathrm{RBC}$ & $474 \times 10^{4} / \mathrm{mm}^{3}$ & (3) Coagulation & \\
\hline $\mathrm{Hb}$ & $14.1 \mathrm{~g} / \mathrm{d} l$ & Bleeding time & $1^{\prime} 30^{\prime \prime}$ \\
\hline $\mathrm{Ht}$ & $43.5 \%$ & APTT & $36.5 \mathrm{sec}$ \\
\hline WBC & $8400 / \mathrm{mm}^{3}$ & PT & $10.7 \mathrm{sec}$ \\
\hline ESR & $8 \mathrm{~mm} / 1 \mathrm{~h}, 22 \mathrm{~mm} / 2 \mathrm{~h}$ & (4) Serology & \\
\hline \multicolumn{2}{|l|}{ (2) Biochemistry } & $\mathrm{CRP}$ & $(-)$ \\
\hline T. Bil & $0.8 \mathrm{mg} / \mathrm{d} l$ & RA & $(-)$ \\
\hline D. Bil & $0.1 \mathrm{mg} / \mathrm{d} l$ & (5) Stool & \\
\hline GOT & $21 \mathrm{U} / \mathrm{L}$ & Occult Blood & $(-)$ \\
\hline GPT & $16 \mathrm{U} / \mathrm{L}$ & (6) Tuberculin reaction & \\
\hline LDH & $226 \mathrm{U} / \mathrm{L}$ & $14 \times 17$ & \\
\hline ALP & $149 \mathrm{U} / \mathrm{L}$ & $48 \times 47$ & \\
\hline$\gamma-\mathrm{GTP}$ & $20 \mathrm{U} / \mathrm{L}$ & (7) Tumor marker & \\
\hline LAP & $209 \mathrm{GR}$ & AFP & $5 \mathrm{ng} / \mathrm{m} l$ \\
\hline ChE & $1.15 \mathrm{D}-\mathrm{PH}$ & CEA & $0.7 \mathrm{ng} / \mathrm{ml}$ \\
\hline Chol & $193 \mathrm{mg} / \mathrm{d} l$ & CA19-9 & $6 \mathrm{U} / \mathrm{m} l$ \\
\hline Amylase (S) & $215 \mathrm{IU} / \mathrm{L}$ & IAP & $496 \mu \mathrm{g} / \mathrm{m} l$ \\
\hline
\end{tabular}

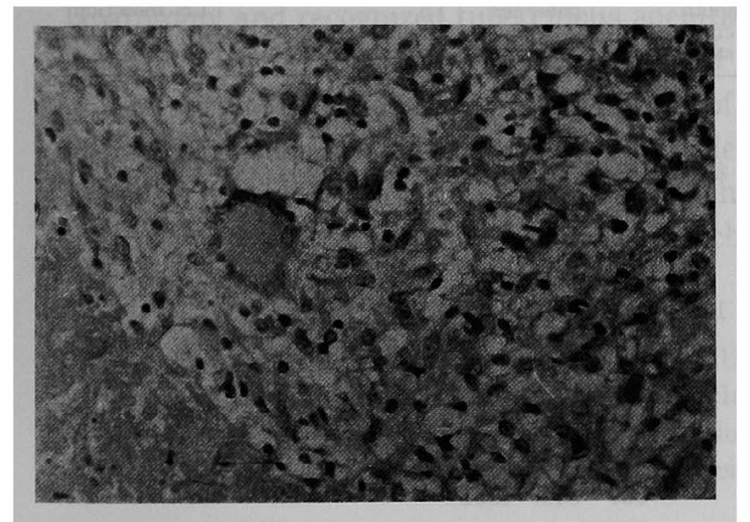

Fig. 7 Tuberculous Lymphadenitis. Photomicrograph showing granuloma with caseation and multinucleated ginat cell. H.E. $\times 400$

かった (Table 2).

消化管造影：十二指腸球部にニッシェを認め，十二 指腸潰瘍と診断した。

腹部超音波検查: 膵頭部に直径約 $3 \mathrm{~cm}$ の $\mathrm{low}$ echoic massを認めた。

ERCP : 総胆管下部に辺縁平滑な王排像を認めた。

腹部 CT 検查：plain CT にて膵頭部腫瘤を認め, enhance CT にて腫瘤辺縁部はリング状に enhanceさ れ, 内部に結節様にenhanceされる部位と全く enhanceを受けない部位を認めた（Fig. 6).

手術所見：総胆管，十二指腸球部，胆裹に接し連大 したリンパ節膿瘍を認めた。 胆変摘除及び膿瘍ドレ
ナージ術を施行した。

組織像：腫大したリンパ節の中央に乾酪壊死巣を認 め, 周辺には類上皮細胞㧍よびラングハンス巨細胞が みられ，結核性リンバ節炎と診断した (Fig. 7).

両症例とも術後外来にて抗結核療法を続行し, 経過 は順調である。

\section{考 察}

良性胆管狭窄の原因としては，術後の瘦痕狭窄・慢 性膵炎・阳石などがある。中でも徒後般痕狭窄が最も 多く，横满ら ${ }^{1)}$ は良性胆管狭窄 25 例中 11 例 (48\%) 亿見 られたと報告している。しかし，結核性リンパ節炎に よる総胆管狭窄は極めて稀であり ${ }^{1-5)}$, 本邦で我々の調 べ得た限りでは，自験例 2 例をあわせ 7 例のみである (Table 3). 自験例 1 例を除く6例においては, いずれ も術前において悪性腫煌や急性胆襄炎と診断されてお $\eta^{1 \sim 5)}$ ，術前診断の困難なことを示している。

一般に消化器疾患に抢ける結核症は, 決して稀なる のではない，肝胆道系結核症においては granuloma tous hepatitisは，しばしばみられる10). しかし，胆道 結核・結核性リンパ節焱やそれによる胆道狭窄の報告 は上述のごとく極めて少ない。一方国外の報告では， Alvarez らは, フィリピンに括ける130例の hepatobiliary tuberculosis のうち45例 (35\%) の経過中 に閉塞性黄疸を認め, 結石や悪性腫瘍との鑑別には肺 結核の合併の有無や chronicity が有用であると述べ ている6)。ところが肺結核を合併していない症例す多 く $(65 \%)^{6)}$, 術前診断には困難を伴う. Barbalinardo 
Table 3 Previously reported cases of biliary tract stenosis due to tuberculous adenitis in Japan.

\begin{tabular}{|c|c|c|c|c|c|c|c|c|}
\hline \multirow{2}{*}{ author } & \multirow{2}{*}{ age/sex } & \multirow{2}{*}{ clinical features } & \multirow{2}{*}{$\begin{array}{l}\text { history of } \\
\text { tuberculosis }\end{array}$} & \multicolumn{4}{|c|}{ diagnosis } & \multirow{2}{*}{ therapy } \\
\hline & & & & chest X-P & PTC/ERCP & echo/CT & pre ope. Dx & \\
\hline $\begin{array}{l}\text { Mori } \\
(1959)\end{array}$ & $28 \mathrm{~F}$ & $\begin{array}{l}\text { fever up } \\
\text { upper abd. pain } \\
\text { jaundice }\end{array}$ & $(-)$ & $\begin{array}{l}\text { calcified } \\
\text { shadow }\end{array}$ & & & $\begin{array}{l}\text { acute } \\
\text { cholecystitis }\end{array}$ & LN resection \\
\hline $\operatorname{Ima}_{(1966)}$ & $35 \mathrm{~F}$ & $\begin{array}{l}\text { rt. } \\
\text { hypochondralgia } \\
\text { jaundice }\end{array}$ & $(+)$ & $\begin{array}{c}\text { calcified } \\
\text { shadow }\end{array}$ & $\begin{array}{l}\text { smooth } \\
\text { compression } \\
\text { stenosis }\end{array}$ & & & $\begin{array}{l}\text { LN resection } \\
\text { cholecyst- } \\
\text { d u o de n o s- } \\
\text { tomy }\end{array}$ \\
\hline $\begin{array}{l}\text { Nariyama } \\
(1978)\end{array}$ & $25 \mathrm{~F}$ & $\begin{array}{l}\text { nausea } \\
\text { jaundice }\end{array}$ & $(-)$ & $\begin{array}{c}\text { nodular } \\
\text { shadow }\end{array}$ & $\begin{array}{l}\text { smooth } \\
\text { compression } \\
\text { stenosis }\end{array}$ & & $\begin{array}{l}\text { chr. } \\
\text { pancreatitis } \\
\text { pacreas head ca. } \\
\text { Tb. lymphadenitis }\end{array}$ & $\begin{array}{l}\text { LN resection } \\
\text { choledoco- } \\
\text { jejunostomy }\end{array}$ \\
\hline $\begin{array}{l}\text { Yokomizo } \\
\text { (1981) }\end{array}$ & $21 \mathrm{~F}$ & $\begin{array}{l}\text { rt. } \\
\text { hypochondralgia } \\
\text { vomit, diarrhea } \\
\text { jaundice }\end{array}$ & $(-)$ & $\begin{array}{l}\text { no } \\
\text { abnormal } \\
\text { findings }\end{array}$ & $\begin{array}{l}\text { smooth } \\
\text { compression } \\
\text { stenosis }\end{array}$ & $\begin{array}{l}\text { pancreas } \\
\text { head } \\
\text { mass }\end{array}$ & $\begin{array}{l}\text { pancreas head } \\
\text { malignant tumor }\end{array}$ & $\begin{array}{l}\text { LN resection } \\
\text { T-tube } \\
\text { drainage }\end{array}$ \\
\hline $\begin{array}{l}\text { Sudoh } \\
\text { (1984) }\end{array}$ & $27 \mathrm{M}$ & $\begin{array}{l}\text { rt. } \\
\text { hypochondralgia } \\
\text { anorexia, jaundice }\end{array}$ & $(+)$ & \begin{tabular}{|l|} 
no \\
abnormal \\
findings
\end{tabular} & $\begin{array}{l}\text { smooth } \\
\text { compression } \\
\text { stenosis }\end{array}$ & & $\begin{array}{l}\text { lymphadenitis } \\
\text { malignant tumor }\end{array}$ & LN resection \\
\hline $\begin{array}{l}\text { Katayama } \\
(1986)\end{array}$ & $28 \mathrm{M}$ & $\begin{array}{l}\text { rt. } \\
\text { hypochondralgia } \\
\text { fever up, jaundice }\end{array}$ & $(+)$ & $\begin{array}{l}\text { nodular } \\
\text { shadow }\end{array}$ & $\begin{array}{l}\text { smooth } \\
\text { compression } \\
\text { stenosis }\end{array}$ & $\begin{array}{l}\text { pancreas } \\
\text { head } \\
\text { swelling }\end{array}$ & $\begin{array}{l}\text { pancreas head } \\
\text { tumor }\end{array}$ & $\begin{array}{l}\text { LN resection } \\
\text { choledoco- } \\
\text { jejunostorny }\end{array}$ \\
\hline $\begin{array}{l}\text { Katayama } \\
(1986)\end{array}$ & $20 \mathrm{~F}$ & upper abd. pain & $(-)$ & $\begin{array}{l}\text { no } \\
\text { abnormal } \\
\text { findings }\end{array}$ & $\begin{array}{l}\text { smooth } \\
\text { compression } \\
\text { stenosis }\end{array}$ & $\begin{array}{l}\text { pancreas } \\
\text { head } \\
\text { mass }\end{array}$ & $\begin{array}{l}\text { Tb. } \\
\text { lymphadenitis } \\
\text { pancreas tumor }\end{array}$ & $\begin{array}{l}\text { LN resection } \\
\text { abscess } \\
\text { drainage }\end{array}$ \\
\hline
\end{tabular}

らは，脺頭部腫瘍に類似した後腹膜のリンパ節結核の 症例を経験し，確定診断のためには開腹の必要性を述 ベている7).

これまでの本疾患の報告での画像診断では，CT 検 查にて石灰化を伴った結節像泉 ・中心に low density areaを伴ない，造影にて周辺が enhance される mass 像") ${ }^{7}$ lobulated irregular mass 像泉等の所見が指摘さ れているが，悪性腫湯き膿場などとの鑑別が問題であ る. しかし自験例 2 例の CT 像は，本疾患を示唆する 共通点がみられる。即ち plain-CT にて膵頭部領域に 腫瘤がみられ，enhance-CTにて腫瘤辺縁はリング状 に enhance され, 内部に enhance される結節像と全く enhanceされない, water densityの部分を認めた。手 術所見と対比し，腫瘤辺縁部の膿湯壁と内部の乾酪肉 芽腫巣が enhance され, 内部の膿汁が全く enhanceさ れない部分に当たると考えられた．結核性リンバ節炎 が，膿汁と乾酪肉芽腫を伴 5膿瘍を造ることを考える と, 本症に特徽的な所見と思われる. 本症は膿汁を除 去する必要性から，開腹は避けられないと考劣られる が，腫漡と膿瘍の手術術式の違いを考えると，本所見 は術前の画像診断として重要であると考えられた。

$$
\text { 結語 }
$$

結核性リンハ節炎による総胆管狭窄の 2 症例を経験 し，画像診断上本症の診断に注目すべき有用な所見を
得たので報告した。

本論文の要旨は第21回日本肝葴学会西部会（長崎1986年 12月)にて発表した。

\section{文 献}

1) 横溝清司, 岡部正之, 矢野 真, 他：結核性 リンハ

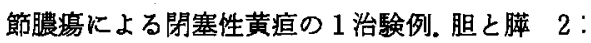
$539-545,1981$

2）森富雄, 三上亮二郎, 荘司貞男, 他 : 胆道リンハ 節結核 (W. Remmele und K. Lennert). 日結 $18: 716-719,1959$

3）今 寛, 横田康正, 吉沢俊裕, 他 : 胆道リン八節 結核による閉塞性黄疸の 1 例。日内誌 55 ： 913-914, 1966

4）成山多喜男, 徍 保敏, 森本 健, 他：結核性リン 節炎による総胆管狭窄の 1 治験例. 外科診療 $20: 223-228,1978$

5）須藤捘之, 吉原綾子, 森山祐三, 他：結核性 リンパ 節炎に上る総胆管㹨窄の 1 例。胆と膵 5 ： 473-477, 1984

6) Alvarez SZ, Carpio R: Hepatobiliary tuberculosis. Dig Dis Sci 28 : 193-200, 1983

7) Barbalinardo RJ, Hamilton GB, Eliot GR, et al : Tuberculous retroperitoneal lymphadenopathy mimicking metastatic pancreatic carcinoma. J 
Natl Med Assoc 78: 385-387, 1986

8) Stanley JH, Yantis PL, Marsh WH : Periportal tuberculous adenitis: A rare cause of obstructive jaundice. Gastrointest Radiol 9 : 227 $-229,1984$

9) Murphy TF, Gray GF : Biliary tract obstruc- tion due to tuberculous adenitis. Am J Med 68 : $452-454,1980$

10) Sherlock S: Diseases of the liver and biliary system. Blackwell scientific publications, Oxford, $1985,460-461$

\title{
Two cases of biliary tract stenosis caused by tuberculous adenitis
}

\author{
Kazuhiro Katayama*1, Hiroshi IKawa*2, Masayoshi Azuma*2, Hiroaki YoshiokA*2, \\ Hiroshi IshnzU*2, Toru Kashiwagi*2, Natsuki MrtsuTaNI*2, \\ Takeo KoIzUMI*2, Keiji Kuwata*3, Yasushi KobaYASH'*4 \\ and Takenobu KAMADA*1
}

We report 2 cases with biliary tract stenosis caused by tuberculous adenitis. One patient was 28 year old man who presented symptom and biochemical evidence of biliary tract obstruction. By CT scan and ultrasonography, a mass in the region of head of pancreas was detected. He underwent laparotomy and recognized tuberculous adenitis of periportal lymph node which caused biliary tract stenosis. The other patient was 20 year old woman who complained abdominal discomfort. An abdominal sonogram revealed a mass at head of pancreas. She underwent laparotomy which revealed tuberculous adenitis of periportal lymph node. The CT scan showed soft tissue mass at head of pancreas. Ring enhancement and nodular enhancement of the mass were observed in both of the cases. This sign of CT scan was thought to be characteristic of tuberculous adenitis and useful for preoperative diagnosis.

*1 First Department of Internal Medicine, Osaka University of Medicine (Osaka)

*2 Department of Internal Medicine, Osaka Kouseinenkin Hospital (Osaka)

*3 Department of Surgery, Osaka Kouseinenkin Hospital (Osaka)

*4 Department of Clinical Pathology, Osaka Kouseinenkin Hospitaal (Osaka) 